February 2015

\title{
Literature review on rebound effect of water saving measures and analysis of a Spanish case study
}

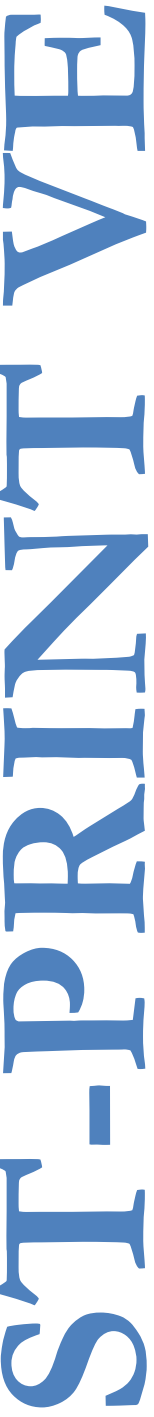

Julio Berbel

Carlos Gutiérrez-Martín

Juan A. Rodríguez-Díaz

Emilio Camacho

Pilar Montesinos

Paper accepted to be published in Water Resources Management

Editorial: Springer ISSN: 0920-4741

http://dx.doi.org/10.1007/s11269-014-0839-0

Berbel, J., Gutiérrez-Martín, C., Rodríguez-Díaz, J.A., Camacho, E. and Montesinos, P. (2015). Literature review on rebound effect of water saving measures and analysis of a Spanish case study. Water Resources Management 29(3):663-678.

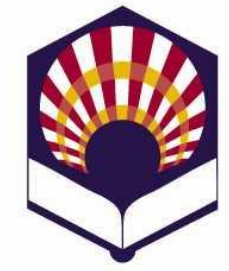

UNIVERSIDAD E CORDOBA 


\title{
Literature review on rebound effect of water saving measures and analysis of a Spanish case study
}

\author{
Julio Berbel ${ }^{\mathrm{a}, 1}$, Carlos Gutiérrez-Martín ${ }^{\mathrm{a}}$, Juan A. Rodríguez-Díaz ${ }^{\mathrm{b}}$, Emilio Camacho ${ }^{\mathrm{b}}$ and \\ Pilar Montesinos ${ }^{\mathrm{b}}$. \\ ${ }^{a}$ University of Cordoba. Campus Rabanales. Ctra N-IV km 396. Edificio Gregor \\ Mendel. 14071 Córdoba - Spain \\ ${ }^{\mathrm{b}}$ University of Cordoba. Campus Rabanales. Ctra N-IV km 396. Edificio Leonardo \\ da Vinci. 14071 Córdoba - Spain
}

\begin{abstract}
The hypothesis of a rebound effect as a consequence of water saving investments is taken analogically from the Jevons paradox models in energy economics. The European Commission (EC) alert about the consequences in water stressed regions that are investing heavily in modernization of irrigation networks and systems. This paper reviews the literature, linking water savings with water diversion and water depletion, both from theoretical models and empirical evidence from the published research. In order to increase knowledge of this phenomenon, a new empirical case study is presented based on a survey of 36,000 ha of recently modernized irrigated areas in the Guadalquivir basin (southern Spain). The results of the case study illustrates the conditions that may avoid rebound effect, although the results of the available empirical evidence and the published theoretical research are diverse and lead to contradictory results. Further research is therefore needed to determine the causes and solutions of water saving investment impacts and the possible speculative rebound effect.
\end{abstract}

Keywords: Water conservation; Jevons paradox; Rebound effect; Water pricing; Water use; Water consumption; Spain

\section{Highlights}

- The present study analyzes the theoretical and empirical evidence that water saving investments may lead to increased water use and/or consumption.

- Some authors suggest that if irrigated land expansion is not constrained, increased water abstractions are likely to occur.

- When land expansion is constrained and water rights are controlled, water depletion does not increase.

- The results of published research are diverse and have yielded contradictory results regarding the rebound effect as a consequence of water saving investments.

\footnotetext{
${ }^{1}$ Julio Berbel. e-mail: berbel@uco.es, Tel.: +34 957218456, Fax: +34 957218457
} 


\section{Literature review on rebound effect of water saving measures and analysis of a Spanish case study}

\section{Introduction}

The analysis of the irrigation modernization rebound effect is an urgent scientific task. The rebound effect is the proposition that the increase in efficiency of use of a resource tends to increase (rather than decrease) the rate of consumption of that resource. The European Commission (2012) has recently identified this effect as a potential problem and it has received attention in the academic sphere. Irrigation modernization, which is understood as the enhancement of efficiency, flexibility and reliability through the transformation of water delivery and application systems, may have consequences in terms of the amount of water used and consumed.

Water scarcity is a growing concern on the environmental policy agenda and a structural problem in arid and semi-arid regions across the world. In the Mediterranean region, the problem of demand exceeding sustainable supply has been tackled recently with 'demand side' policies, particularly through investment in water saving technologies and reduction of losses in distribution networks associated to the promotion of water pricing. The public policy supporting network improvement and water saving investment has been implemented since 1996 and receives the name of 'modernization' as defined in the Spanish National Irrigation Program (MAPA, 2001).

To investigate a potential rebound effect in irrigation, it is important to distinguish between water use (extraction) and water consumption as only part of the extracted water is consumed in irrigation agriculture. The extracted water ends up as: (1) beneficial evapotranspiration; (2) non-beneficial evapotranspiration; (3) non-recoverable runoff/percolation; and (4) recoverable runoff/percolation (Burt et al. 1997). The first three components constitute the consumed or depleted fraction, implying that water is not available for further use as it is consumed as evapotranspiration, incorporated into a product, flows to a location where it cannot be readily reused, or becomes heavily loaded with salts.

The Water Framework Directive (WFD, EC 2000) promotes the use of full cost recovery (including environmental and resource costs) as an efficient measure to reduce water demand and reach a sort of sustainable and win-win situation. Many authors have argued that water pricing is useless when water has a higher value and farmers adapt to deficit irrigation due to the structural scarcity of the region (e.g. Berbel and Gómez Limón 2000; De Fraiture and Perry 2002; Berbel and Mateos 2014). Water pricing advocates, however, do not consider this a relevant argument and believe that increasing water price is the main solution to reach the sustainable nirvana. Following a critical analysis of the ten years since the WFD was implemented, the EC (2012) proposed a 'blueprint' to improve the state of water bodies in Europe and announced a future revision of the WFD by 2019. The EC (2012) has raised public awareness about the rebound effect assuming that there exists an analogy of energy economics (Jevons paradox), although caution must 
be taken with the analogy due to differences between water and energy. The EC (2012) document fully accepts the rebound effect without questioning scientific evidence, and simultaneously promotes 'water pricing' as a solution to the hypothetical rebound effect.

The European Commission (2012) has taken a simplistic approach to the problem as a result of the dominant ideology advocated by a network of institutions (environmental NGOs, political bodies and research institutes) that support this type of narrative: irrigation demand is inefficient because water cost is heavily subsidized and consequently, water is too cheap. When water price increases, the demand will be reduced and then sustainability is achieved.

An example of this narrative can be found in reports issued by the European Environmental Agency (EEA), which include statements such as the following: "[...] increasing irrigation water prices to meet full cost recovery would maximise water use efficiency" (EEA 2012:34). However, this statement contradicts the empirical observation contained in the same document, which holds that water-conserving investments depend on "incentives generated by quantity constraints and the limited role of prices" (EEA 2012:43).

This paper is organised into two main sections. Firstly a case study in southern Spain is presented to illustrate the situation 'ex ante' and 'ex post' of water saving investment concluding that presently there is not any rebound effect observed. Secondly the results of this case are confronted with the contradictory results of the published research on the rebound effect.

\section{Case study: Impact of water-conserving investments in the Guadalquivir}

The Spanish Government developed the National Irrigation Plan (MAPA, 2001) with the aim of converting the old open channel distribution infrastructure into pressurized pipe networks and to achieve annual water savings of 3,000 $\mathrm{Mm}^{3}$. These new pressurized pipe systems operate on demand, which has allowed high frequency irrigation, optimal crop irrigation scheduling, and the diversification of cropping patterns towards higher value crops (Fernández-García et al. 2014). The modernization of irrigated systems and projected water savings is a key measure in the implementation of River Basin Management Plans (RBMP) in Spain. Berbel et al. (2012) described the role of water saving measures in the implementation of the WFD in the Guadalquivir River in southern Spain.

The hydrological plans in Spain have been developed in line with the WFD agenda (EC 2000). They include water saving investment measures as part of the RBMP. The Guadalquivir River Hydrological Plan (Berbel et al. 2012) includes water provisions linked to water savings that amount to $25 \%$ of water rights prior to investment. These provisions are imposed by the government in order to improve water management 
sustainability. Berbel et al. (2011) analysed the cost effectiveness of water saving measures in the basin and studied the impact of deficit irrigation.

This section presents original empirical research based on large Water User Associations (WUAs) in the Guadalquivir River Basin. The Guadalquivir River is the longest river in southern Spain with a length of around $650 \mathrm{~km}$. The basin covers an area of $57,527 \mathrm{~km}^{2}$ and has a population of 4,107,598 inhabitants. It has a Mediterranean climate with a heterogeneous precipitation distribution. The annual average temperature is $16.8^{\circ} \mathrm{C}$ and the mean annual precipitation is $573 \mathrm{~mm}$, with a range of $260-983 \mathrm{~mm}$ (standard deviation of $161 \mathrm{~mm}$ ). A description of the evolution of the basin can be found in Berbel et al. (2013). The RBMP focuses on improving water quality through urban sanitation and reducing the quantitative gap through water-conserving investments (called modernization) as an increase in supply is not considered. The RBMP has not contemplated new irrigated areas since 2005 (Berbel et al. 2013).

Figure 1. Guadalquivir River Basin

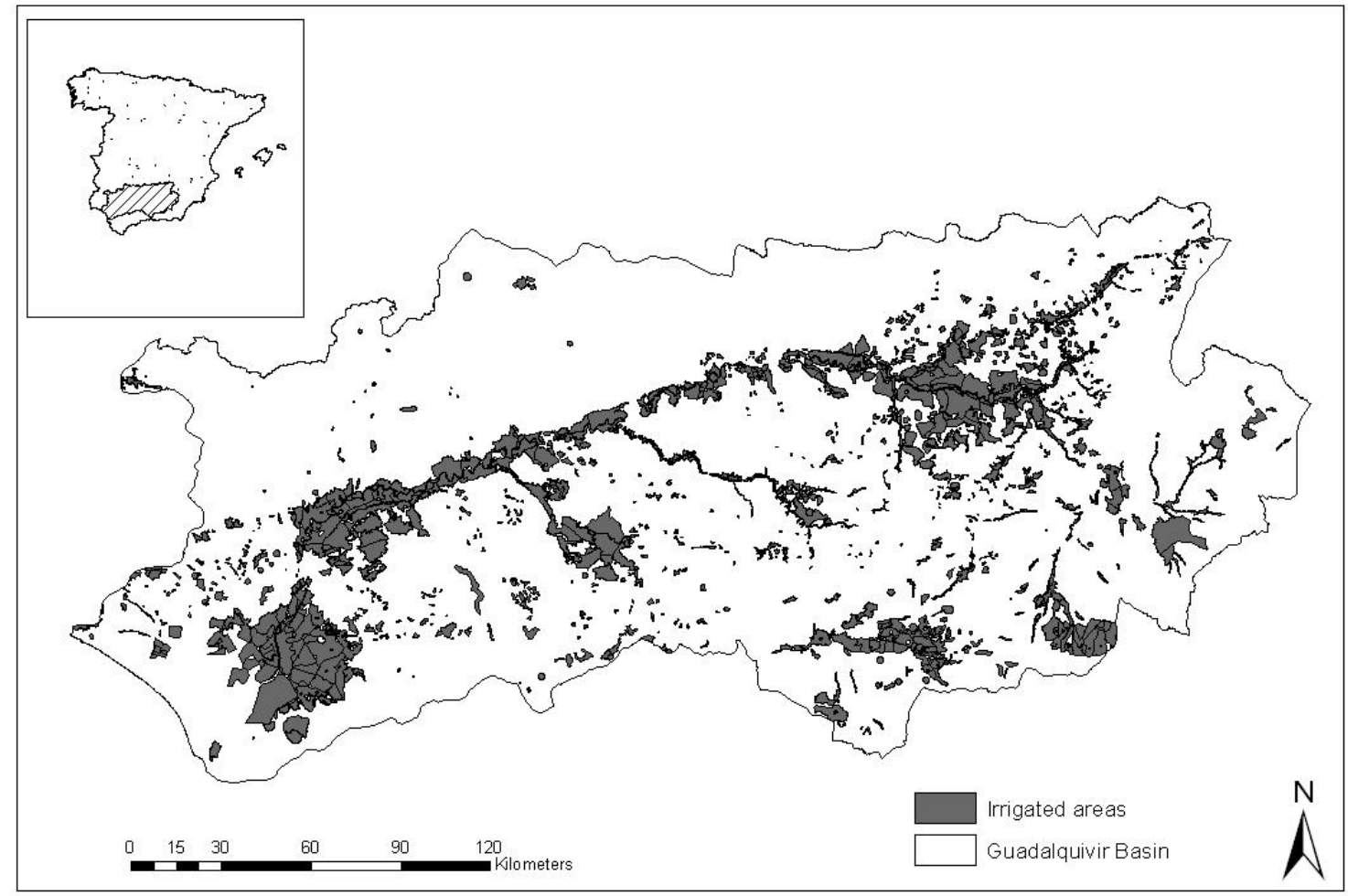

The survey of WUAs is interesting because it covers a significant area (around 36,000 ha) in different locations of the Guadalquivir valley that went through water-conserving investments during the 2005-2008 period. Location of selected areas can be seen in Figure 1. We initially had good quality data from the 1999-2001 period and we made a new survey for the 2009-2011 seasons when farmers were adapted to the new situation. The new infrastructures have been fully working for 2-3 seasons. Thus, this sample is representative of an intensive transformation process where open channels and surface irrigation have been converted to pressurized networks and drip or sprinkler irrigation. Complete information on the main parameters (water diverted, irrigated area, water cost, crop distribution, etc) can be found in Fernández-García et al. (2014). 
Table 1 summarizes the main indicators. Average water use prior to the investment was $6,525 \mathrm{~m}^{3} \mathrm{ha}^{-1}$, which is below the allocated water rights (on average $8,000 \mathrm{~m}^{3} \mathrm{ha}^{-1}$ ). Applied water was slightly below the estimated irrigation needs that are computed as crop evapotranspiration, $\mathrm{ET}_{\mathrm{c}}$, as a function of the potential evapotranspiration and the crop coefficient (Allen et al. 1998) minus the effective rain.

Table 1. Main indicators for a sample of water conserving investment in the a survey of Guadalquivir River Basin WUA

\begin{tabular}{lccc}
\hline \multicolumn{1}{c}{ Year } & $\mathbf{1 9 9 9 - 2 0 0 2}$ & $\mathbf{2 0 0 9 - 2 0 1 2}$ & Increase \\
\hline Irrigated area $(\mathrm{ha})$ & 36,040 & 33,132 & $-8 \%$ \\
Water rights $\left(\mathrm{m}^{3} \mathrm{ha}^{-1}\right)$ & 8,000 & 6,000 & $-25 \%$ \\
Water use $\left(\mathrm{m}^{3} \mathrm{ha}^{-1}\right)$ & 6,526 & 5,159 & $-21 \%$ \\
ETc & 8,259 & 8,405 & $+2 \%$ \\
Effective Rain $\left(\mathrm{m}^{3} \mathrm{ha}^{-1}\right)$ & 1,556 & 2,372 & $+52 \%$ \\
Irrigation needs $\left(\mathrm{m}^{3} \mathrm{ha}^{-1}\right)$ & 6,703 & 6,033 & $-10 \%$ \\
Relative Irrigation Supply (RIS) & 0.97 & 0.86 & $-12 \%$ \\
Water costs $\left(€ \mathrm{ha}^{-1)}\right.$ & 249 & 278 & $+11 \%$ \\
Water costs $\left(€ \mathrm{~m}^{-3}\right)$ & $€ 0.038$ & $€ 0.053$ & $+41 \%$ \\
$\%$ Energy costs & $25 \%$ & $43 \%$ & $+77 \%$ \\
Crops & Cotton $(26 \%)$ & Citrus $(23 \%)$ & Citrus $(+13 \%)$ \\
& Maize $(24 \%)$ & Cotton $(22 \%)$, & Cotton $(-4 \%)$ Maize \\
& Sugarbeet $(18 \%)$ & Maize $(16 \%)$ & $(-8 \%)$ Sugarbeet $(-$ \\
& Citrus $(9 \%)$ & Sugarbeet $(8 \%)$ & $10 \%)$ Vegetables \\
& Vegetables $(4 \%)$ & Vegetables $(5 \%)$ & $(+1 \%)$ Other $(+5 \%)$ \\
\hline
\end{tabular}

Source: Fernández-García et al. (2014). Water use refers to controlled abstraction and water consumption is computed by estimating evapotranspiration minus usable rain.

Note: Data on crops and irrigated area refer to the 2001/2002 season; the remaining variables are the average for the 1996-2001 period.

The Spanish government subsidized around $60 \%$ of the investment cost of the modernization process, while farmers were responsible for financing the remaining $40 \%$ and are fully responsible for the operation and maintenance. The average total investment in the surveyed areas amounted to $6,000 € \cdot \mathrm{ha}^{-1}$. The cost of water increased from 0.038 to $0.054 € \cdot \mathrm{m}^{-3}$ (41\% increase). This higher cost was due to new operating and maintenance costs, particularly because the cost of energy increased from an average of $25 \%$ of total water costs before the investment, to around $43 \%$ after the conversion.

The legal conditions for obtaining the government subsidies were defined as:

- Assumption of the remaining capital cost (40\%) of the capital investment

- Reduction of water rights from the existing $8,000 \mathrm{~m}^{3} \mathrm{ha}^{-1}$ to $6,000 \mathrm{~m}^{3} \mathrm{ha}^{-1}$

- Implementation of water metering and volumetric billing

- No increase in irrigated area

This policy has led farmers to substitute the existing crops for crops of higher value (increase in citrus and vegetable crops, reduction in sugar beet, cotton and maize crops), reduce water use and maintain irrigation water depletion. The government does not allocate the reduction of irrigation allocations for any consumptive use, but keeps it for improving the water balance and environmental goals $\left(2,000 \mathrm{~m}^{3} \mathrm{ha}^{-1}\right.$ equivalent to $25 \%$ of previous water rights). 
In our case study, we found that there was no rebound effect as the farmers complied with the abovementioned legal conditions, namely the (1) strict limitations placed on the size of the irrigated area, (2) the reduction of former water rights, and (3) the reassignation of water savings to achieve environmental goals. These three conditions in our opinion are the key for avoiding rebound effect, and the next sections will review the theoretical and empirical evidence on the phenomena.

\section{Theoretical models}

Various theoretical approaches have been used to analyse the rebound effect, such as analytical models and mathematical programming and simulation. A short summary of these models is presented in Table 2.

\subsection{Analytical models}

Gómez-Gómez and Pérez-Blanco (2014) used a simple analytical microeconomic model with important shortcomings: a) the model did not differentiate between water diversion (irrigation or water use) and water depletion (evapotranspiration or water consumption); b) it did not integrate agronomic models that link water with yield and evaporation; c) it did not include deficit irrigation; and d) it did not analyse water limiting and land limiting policies. All these features of the model were crucial to understanding farmer response and policy options. Unfortunately, the authors did not provide an empirical application of the model where it was tested. The authors concluded that assessing the impact of better irrigation technologies in a particular area remains an empirical question, thus confirming the scarcity of available evidence.

Huffaker (2008) presented another conceptual model with some hydrological and agronomic considerations for the collection of data to predict the conservation of potential subsidies for water saving technologies. According to Huffaker, water conservation policies (such as Oregon's agricultural policy) that guarantee irrigators a portion of conserved water estimated as the reduction in diversions before and after the increase in on-farm efficiency may have adverse consequences. Nevertheless, as in Gómez-Gómez and Pérez-Blanco (2014), Huffaker provides ambiguous results where both the rebound effect and the net water saving outcome are possible.

Scheierling et al. (2006) developed an agro-economic model, concluding that subsidies to irrigation efficiency investment may increase consumptive use "if farmers can expand irrigated acreage use". 


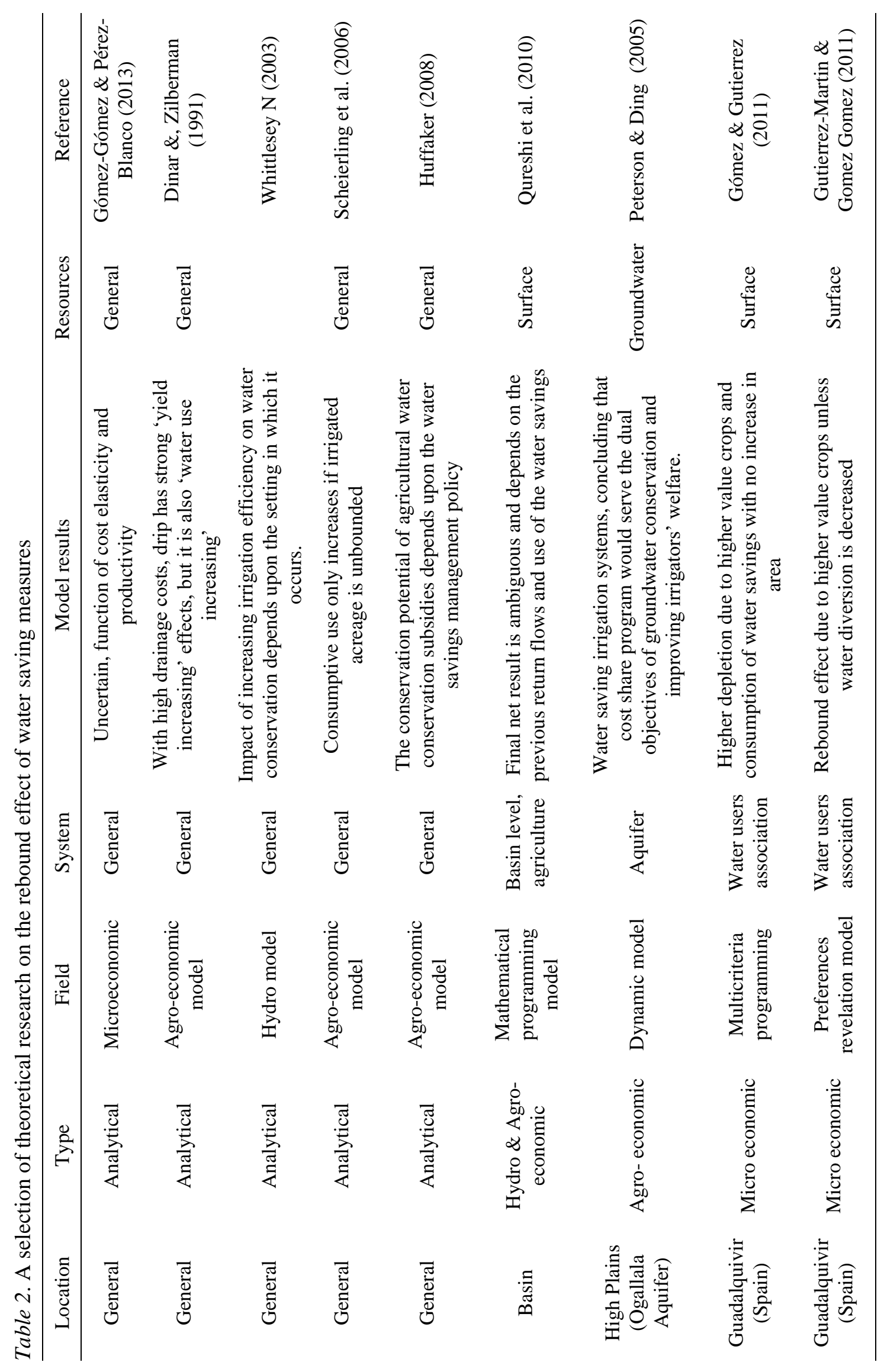




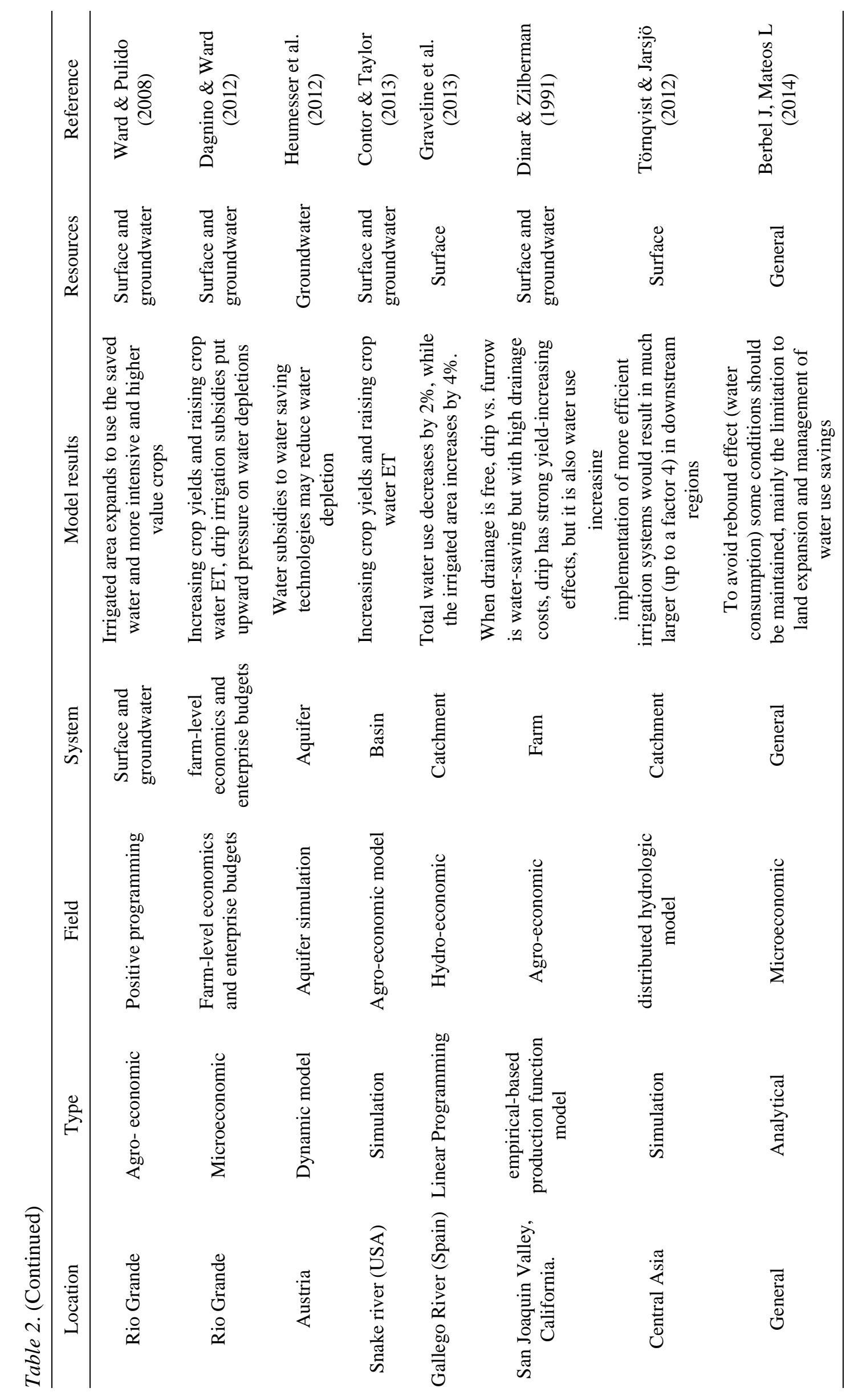


Whittlesey (2003) proposed an analytical framework based on a simplified model that linked crop yield, consumptive water use and applied irrigation. The author examined the conditions under which improving irrigation efficiency actions conserves water.

Dinar and Zilberman (1991) make an analytical microeconomic model of technology adoption applied to irrigation systems concluding that "When drainage is free of cost, the main impact of drip (relative to furrow) is 'water saving'; but it also has a relatively limited 'yield increasing' effect. With high drainage costs, drip has strong 'yield increasing' effects, but it is also 'water use increasing'".

Recently, Berbel and Mateos (2014) propose a simple agro-economic model that explores the conditions under which improved irrigation application uniformity may lead to increased water use and/or consumption. The increase in water depletion due to the introduction of more uniform irrigation systems is insignificant if land is limited and farmers optimize their profit. If land is not a limiting factor, new water abstractions are likely to occur, potentially leading to a vicious circle in which irrigated land expands while water resources become overexploited. Additionally these authors conclude that water demand (the value of marginal water productivity) becomes inelastic as the efficiency increases.

\subsection{Mathematical programming}

Mathematical programming approaches have used different techniques to study the problem, such as linear, dynamic, risk, multicriteria and positive programming.

Based on a mathematical programming model of the Murray Darling basin, Qureshi et al. (2010) concluded that efficiency-improving investments could provide some costeffective opportunities, but also that the final net result is ambiguous and depends on the previous return flows and the use of the water savings. The critical element in most of the published research is the existence of a good water accounting framework.

Peterson and Ding (2005) used a risk programming method to analyse economic adjustments to groundwater depletion in the High Plains (Ogallala Aquifer, USA) as a response to water saving irrigation systems. They concluded that a cost share program would serve the dual objectives of conserving groundwater and improving irrigators' welfare. The authors used a dynamic model to simulate a representative irrigator's optimal technology choice, crop selection, and irrigation water use over time.

An extension of this simple model implemented by a preference revelation model can be found in Gómez and Gutiérrez-Martín (2011). First, they proposed a theoretical model that lacked integration with the agronomic system, and then applied the mathematical model considering a total bounded area (under Spanish regulations) where the projected water increase was based upon the cultivation of higher value crops. Using the same programming model in southern Spain, Gutierrez-Martin and Gomez Gomez (2011) concluded that there is no rebound effect when the irrigated area is limited to the preinvestment limits and water savings are re-allocated from irrigation to water conservation 
objectives. They also found that a water pricing policy would not be effective given the inelasticity of the demand curve in areas with a water deficit.

Ward and Pulido (2008) used positive mathematical programming (PMP) to simulate scaled decreasing returns when an irrigated area is expanded to use the saved water. The anticipated increase of water depletion was due to the increased area and the cultivation of more intensive and higher value crops. PMP accommodates decreasing marginal yields or increasing marginal costs, although one of the drawbacks of PMP is that arbitrary assumptions have to be made (e.g. supply elasticity). PMP is a quadratic programming method and does not analytically integrate agronomic concepts such as efficiency or deficit irrigation.

Dagnino and Ward (2012) provided another approach to analyse the rebound effect using a farm microeconomic model and budget analysis. They concluded that although subsidies for drip irrigation in North America's Rio Grande increased farm income and reduced the amount of water applied to crops, such subsidies could increase water depletion in the basin.

Contor and Taylor (2013) recently developed a simulation model of an irrigation system based upon a theoretical 'ad hoc' approximation to the general function of water response proposed by Martin et al. (1984). The authors concluded that there would be a small rebound effect (consumptive use from irrigation increases by $3 \%$ ) when the model is applied to the Snake River case study.

In contrast to the above authors who support the existence of a rebound effect, Heumesser et al. (2012) used a stochastic dynamic programming model and found that the adoption of water saving investments and subsidies reduces groundwater use in Marchfeld region in Austria.

Graveline et al. (2013) also developed a hydro-economic model for the Gállego catchment (Spain), including the modernization of irrigation technology. The authors found that total water use decreased by $2 \%$, while the irrigated area increased by $4 \%$ in the catchment, and concluded that despite the small increase in irrigated area, modernization does not enable land extension beyond currently available irrigable land.

\section{Empirical research}

We have found a reduced number of publications examining the situation before and after water saving investments, those are condensed in Table 3. When water supply is based upon surface delivery systems, most of the studies conclude that there is a significant reduction in water diversions. Regarding water depletion through evapotranspiration, the analysis of water rebound in the published empirical research considers mainly two policy alternatives:

a) No increase in irrigated area is allowed. 
b) An increase in irrigated area is allowed and only maximum water volume is constrained.

An example of the first case is the Spanish Water Law (Spanish Government 2001), which does not allow water savings to be used to increase irrigated land as water rights strictly define the limits of both the maximum volume of diverted water and the location of irrigated land.

Playán and Mateos (2006) analysed the effects of structural and management changes in the modernization of irrigation. They found that such changes (in Ebro valley, Spain) led to increased productivity, improved water conservation and environmental improvement. However, the effects of this improved efficiency are accompanied by an increase in evapotranspiration.

Other empirical analyses of the transformation of irrigated systems in Spain with the abovementioned land constraints have been conducted by Soto-García et al. (2013), Fernández-García et al. (2014) and García-Mollá et al. (2013). All the authors concluded that water diversion (abstraction) was significantly reduced (by 25\%-45\%), but that water depletion (evapotranspiration) did not increase. They also observed other effects such as a significant increase in water costs, which were mainly due to a 50\%-100\% increase in energy consumption above previous levels, as well as a significant increase in the productivity of land, labour and water.

García-Garizábal and Causapé (2010) also evaluated the environmental impacts of modernization on drainage water and water use in the Bárdenas area of the Ebro River Basin. They concluded that after modernization, the decrease in irrigation drainage in 2007 was a result of the decrease in water requirements $(21 \%)$ and the increase in irrigation efficiency (from 67\% to 93\%), causing the Riguel River to present a lower flow, lower salinity and a lower nitrate concentration.

In contrast, some authors have detected a certain increase in water depletion. This is the case of Lecina et al. (2010), who studied maize and alfalfa crops in the Ebro Basin (northeast Spain), where surface irrigation and open channel networks were converted to sprinkler and pressurized networks. According to the authors, the observed increase may be explained by the evaporation of the drops travelling from the sprinklers to the ground (substitution of surface irrigation for sprinklers) and the irrigation of some plots inside the perimeter of the WUA that received scarce or no irrigation due to the deficiencies of the previous system (surface and open channels). Pfeiffer and Lin (2014) reported a small increase (1\%-2\%) in water depletion when traditional pivots were replaced by dropnozzle pivots. The reasons for the increase in evapotranspiration reported by these authors are unclear from the biophysical point of view and the authors recognized the need for additional research. 


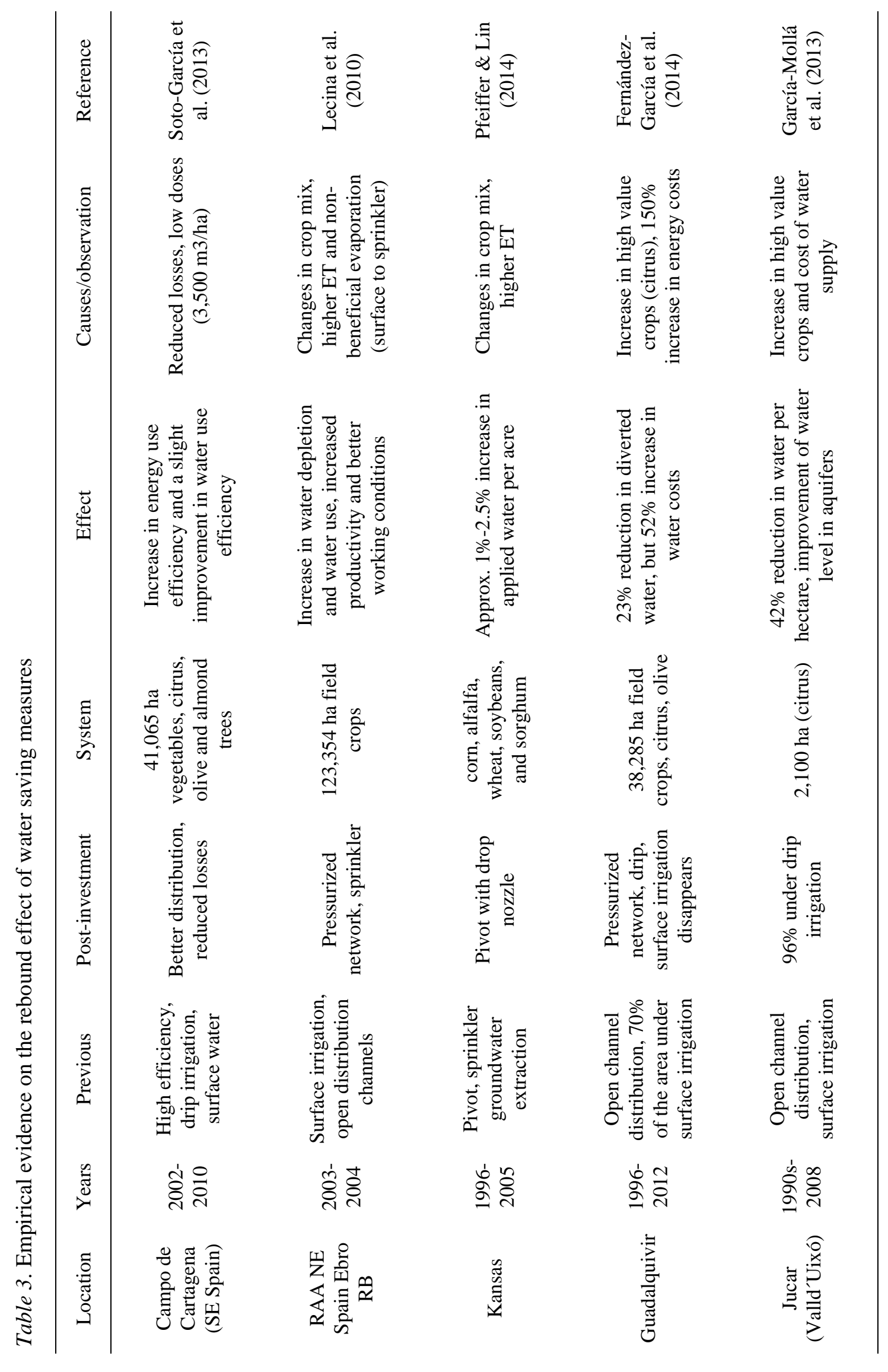




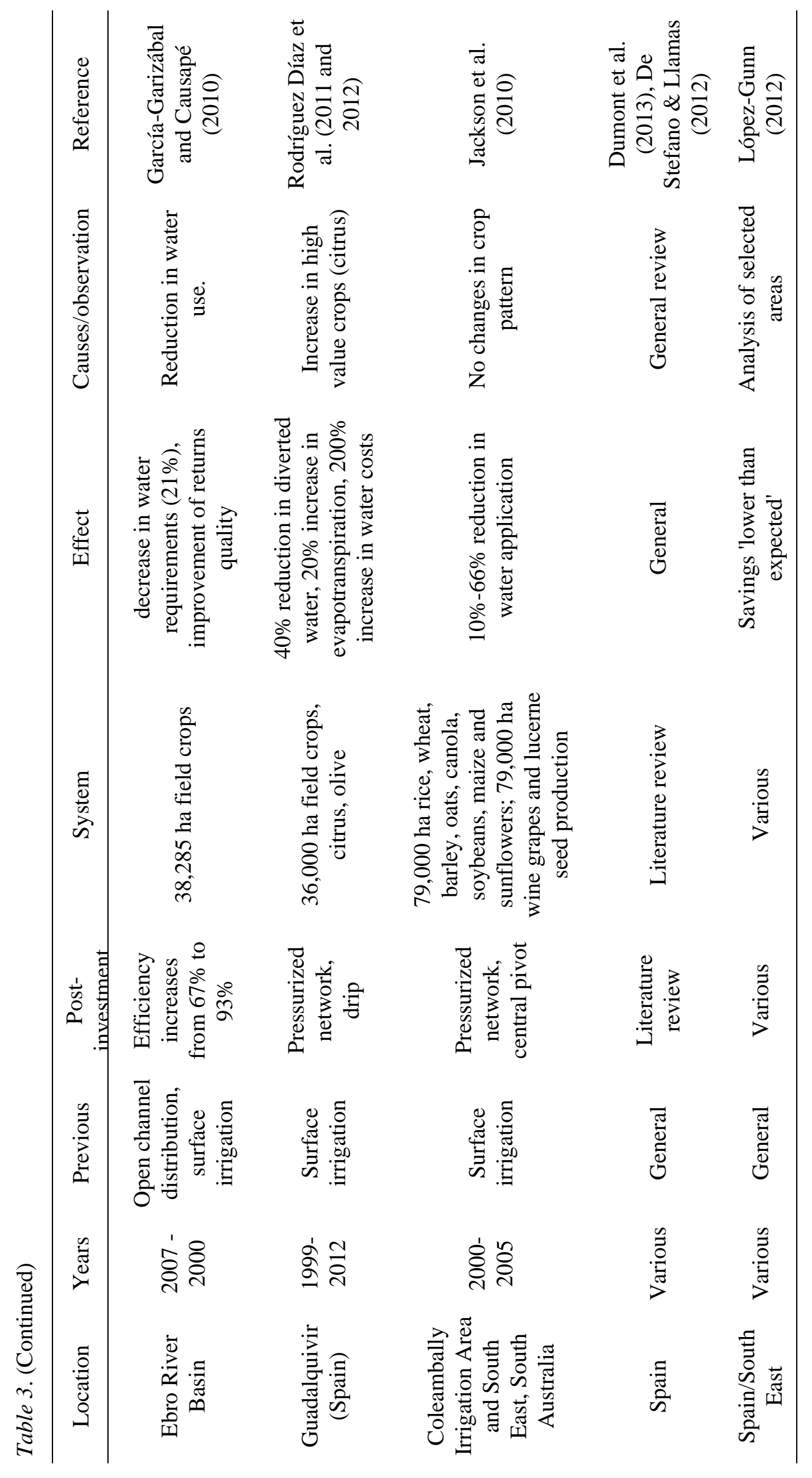


Rodríguez Díaz et al. (2011 and 2012) used performance indicators related to water and energy consumption to analyse systems before and after the process to modernize the irrigation community in Bembézar MD (southern Spain), where surface irrigation systems were substituted for drip irrigation systems. Their analysis showed that approximately $40 \%$ less water was diverted for irrigation due to the greater efficiency of the irrigation systems. However, this situation has led to the adoption of new crop rotations (mainly citrus crops) of higher value and greater water demand, thus increasing the consumptive use of water (ETc) by around 20\%. They also observed a four-fold increase in management, operation and maintenance costs than before modernization mainly due to energy costs, as well as an improvement in the apparent economic productivity as in Lecina et al. (2010).

Jackson et al. (2010) analysed two different irrigation areas in Australia after the conversion of flood irrigation systems into pressurized systems. The results showed a $10 \%-66 \%$ reduction in water use, but as much as a $163 \%$ increase in energy consumption in the area irrigated by surface irrigation systems. In contrast, energy consumption in the groundwater dependent area was reduced by $12 \%$ to $44 \%$ due to the smaller volumes of water pumped as a result of increased application efficiency. However, the authors did not indicate the evolution of evapotranspiration.

Some authors sustain academic positions in line with the dominant opinion supported by the EC and EEA and make some analysis that is summarized also in Table 3. Dumont et al. (2013) made a strong case for the rebound effect in Spain based mainly on the mentioned study of Lecina et al. (2010) in the Ebro Valley, but dismissed other examples that provided evidence to the contrary, which were also cited but not acknowledged.

In this line of narrative, López-Gunn et al. (2012) performed an ex-post analysis of some modernization of irrigation systems in Spain examining some cases where water consumption has been measured ex ante and ex post, concluding that savings have been "lower than expected", nevertheless, the analysis of these authors lacks a clear definition of the water accounting framework adopted.

\section{Discussion}

When traditional surface irrigation systems are replaced by sprinkler and drip irrigation systems, which are characterized by high water application efficiency, water diversion decreases under all circumstances unless the irrigated area is expanded or evapotranspiration may be increased due to changes in crop patterns.

When irrigated land is constrained and water is unbounded, the introduction of more efficiency irrigation systems does not significantly increase evapotranspiration (water consumption). This is because the evapotranspiration from fields irrigated by furrow or drip systems is similar under full irrigation. Subsurface drip irrigation may reduce soil surface evaporation; a non-beneficial component of water consumption. Drop 
evaporation occurring with sprinkler irrigation is another form of non-beneficial consumption. Final impact of modernization in water consumption is uncertain as the differences in irrigation system characteristics, change in crop rotation, introduction of new crops with higher or lower water demand will made a combined global impact that may either increase or decrease water depletion consumption in the long term.

When irrigated land is unconstrained, modernization is likely to lead to new uncontrolled water abstraction, potentially starting a vicious circle in which irrigated land expands while water resources are overexploited. Therefore, water saving measures must be accompanied by instruments to control water abstraction and the expansion of irrigated land. The key for public policy is to understand the difference between pressure reduction (diverted water) and impact reduction (consumed water), that is, the difference between "dry" ("paper") and "wet" ("real") water savings, respectively (Seckler 1996). Again the existence of a satisfactory water accounting is crucial for sustainable public policy.

The evidence of the empirical and theoretical literature review suggest that when traditional surface (furrow) systems are replaced by sprinkler and drip irrigation, water abstraction (use) is reduced in a significant number of studies, among others in: Jackson et al. 2010; López-Gunn et al. 2012; García-Mollá et al. 2013; Soto-García et al. 2013; Graveline et al. 2013; Heumesser et al. 2012; Törnqvist and Jarsjö 2012; Peterson and Ding 2005).

Some authors conclude either from simulation models that rebound effect exists but the magnitude is minor, below 3\% such as Contor and Taylor (2013), Graveline et al. (2013) or by empirical research as in Pfeiffer and Lin (2014), this small increase is justified by increased productivity or crop change.

Other authors give ambiguous results such as Dinar and Zilberman (1991), Qureshi et al. (2010), Huffaker (2008) and Gómez and Pérez (2013) where the final result of water saving investment is ambiguous with the rebound effect that would be a function of water cost and water productivity and the implementation measures selected for financing the water savings policy.

As a conclusion of the review of published research, and regarding the mentioned water management policy conditions for avoiding the rebound effect, the policy options that may avoid any rebound effect implies the achievement of one of several of these conditions:

a) water consumption does not increase significantly unless irrigated area increases allowing farmers to use the 'water savings' (Berbel and Mateos 2014; Ward and Pulido 2008; Graveline et al. 2013; Soto-García et al. 2013; Scheierling et al. 2006).

b) when the quality of infrastructure in previous systems is very deficient (lack of uniformity, fallow land due to water supply restrictions, deficit irrigation applied), the modernization may increase productivity and consequently increase $\mathrm{ET}_{\mathrm{c}}$ (Lecina et al. 2010; Playán and Mateos 2006; Pfeiffer and Lin 2014). 
c) introduction of new crops which are more water intensive is allowed and consequently future $\mathrm{ET}_{\mathrm{c}}$ increases after modernization (Fernandez et al. 2014; Rodríguez-Díaz et al. 2012; Ward and Pulido 2008)

The final section tries to summaries main finding of this research

\section{Concluding remarks}

The proposal by the EU (2012) to use water pricing to counter the rebound effect may be against theoretical and empirical evidence that indicates that marginal water productivity becomes less elastic as the application efficiency of the irrigation system increases (see López-Baldovín et al. 2006; De Fraiture and Perry 2002 or Contor and Taylor 2013). Most of the water scarce regions in the world have implemented subsidies for supporting farmers investment in water saving measures, the evidence regarding the rebound effect is ambiguous and depends upon previous situation and characteristics of both, the agricultural systems and basin or aquifer. Induced changes in crop rotations, increase in productivity due to very deficient previous situation and other factors may increase or decrease water use and water consumption.

As a general conclusion, we believe that according to published body of literature, there is a need for greater knowledge about the dynamic effects of water saving investments, including the rebound effect and economic instruments for the prevention of negative outcomes. As Gleick et al. (2011) argue, we must design appropriate wateraccounting procedures in place (both farm and basin) in order to identify the opportunities for water savings and then apply specific water conservation and efficiency practices based on a combined use of economic, technical, social and political tools to reduce pressures on scarce water supplies.

Therefore additional research in the field of the evaluation of impacts of technical improvements on irrigation water demand is required. Evidences are ambiguous and the combined impact of water saving investment on water use and consumption is uncertain. The differences in the previous situation, basin or aquifer characteristics, induced sometimes changes in crop rotations, and many other factors will made a combined global impact that may either increase or decrease the water use and water consumption rates. Every basin is different, water conservation and efficiency practices offer one set of tools to reduce pressures on scarce water supplies although the mix of tools (economic, technical, social, political) should be adapted to each specific case.

\section{References}

Allen RG, Pereira LS, Raes D, Smith M (1998) Crop evapotranspiration: Guidelines for computing crop water requirements. FAO Irrig and Drain Paper 56

Berbel J \& Gómez-Limón C (2000) The impact of water-pricing policy in Spain: an analysis of three irrigate areas. Agricultural Water Management 43: 219:238 
Berbel J, Kolberg S, Martin-Ortega J (2012) Assessment of the Draft Hydrological Basin Plan of the Guadalquivir River Basin (Spain). Int J Water Resour Dev 28(1):43-56. doi:10.1080/07900627.2012.640875

Berbel J, Mateos L (2014) Does investment in irrigation technology necessarily generate rebound effects? A simulation analysis based on an agro-economic model. Agric Syst 128:25-34. doi: 10.1016/j.agsy.2014.04.002

Berbel J, Martin-Ortega J, Mesa P (2011) A cost-effectiveness analysis of water-saving measures for Water Framework Directive: The case of the Guadalquivir River Basin in Southern Spain. Water Resour Manag 25:623-640. doi:10.1007/S11269-010-97176

Berbel J, Pedraza V, Giannoccaro G (2013) The trajectory towards basin closure of a European river: Guadalquivir. Int J River Basin Manag 11(1):111-119. doi:10.1080/15715124.2013.768625

Burt CM, Clemmens AJ, Strelkoff TS, Solomon KH, Bliesner RD, Hardy LA, Howell TA, Eisenhauer DE (1997) Irrigation performance measures: efficiency and uniformity. J Irrig Drain Eng 123:423-442

Cai X, Rosegrant MW (2003) World water productivity: current situation and future options. In: Kijne JW, Barker R, Molden D (eds.) Water productivity in agriculture: Limits and opportunities for Improvement. CABI Publishing, UK (in association with IWMI, Colombo, Sri Lanka), pp 163-178

Contor BA, Taylor RG (2013) Why improving irrigation efficiency increases total volume of consumptive use. Irrig Drain 62(3):273-280

Dagnino M, Ward FA (2012) Economics of Agricultural Water Conservation: Empirical Analysis and Policy Implications. Int J Water Resour Dev 28(4):577-600. doi:10.1080/07900627.2012.665801

De Fraiture C, Perry C (2002) Why is irrigation water demand inelastic at low price ranges. In Conference on Irrigation Water Policies: Micro and Macro Considerations (pp. 15-17).

Dinar A, Zilberman D (1991) The economics of resource-conservation, pollutionreduction technology selection: the case of irrigation water. Resource Energy 13(4):323-348.

Dumont A, Mayor B, López-Gunn E (2013) Is the Rebound Effect or Jevons Paradox a Useful Concept for better Management of Water Resources? Insights from the Irrigation Modernisation Process in Spain. Aquat Procedia 1: 64-76. doi:10.1016/j.aqpro.2013.07.006

EEA, European Environment Agency (2012) Towards efficient use of water resources in Europe. Report No 1/2012. Luxembourg: Office for Official Publications of the European Union. doi:10.2800/95096, http://www.eea.europa.eu/publications/towardsefficient-use-of-water (accessed on 26 september 2013)

EC, European Commission (2000) Water Framework Directive of the European Parliament and of the Council (2000/60/EC). Brussels. http://eurlex.europa.eu/LexUriServ/LexUriServ.do?uri=CELEX:32000L0060:en:HTML (accessed on 26 september 2013) 
EC, European Commission (2012) A Blueprint to Safeguard Europe's Water Resources, Brussels. $\quad$ http://ec.europa.eu/environment/water/blueprint/pdf/COM-2012673final_EN_ACT-cov.pdf (accessed on 10 october 2013)

Fernández-García I, Rodríguez-Díaz JA, Camacho-Poyato E, Montesinos P, Berbel J (2014) Effects of modernization and medium term perspectives on water and energy use in irrigation districts. Agric Syst (in press)

García-Garizabal I, Causapé J (2010) Influence of irrigation water management on the quantity and quality of irrigation return flows. J Hydrol 385:36-43

García-Mollá M, Sanchis-Ibor C, Ortega-Reig MV, Avellá-Reus L (2013) Irrigation associations coping with drought: the case of four irrigation districts in eastern Spain. In: Schwabe K, Albiac Murillo J, Connor JD, Hassan RM, Meza González L (eds) Drought in arid and semi-arid regions. Springer. Netherlands. pp 101-122. doi:10.1007/978-94-007-6636-5_6

Graveline N, Majone B, Van Duinen R, Ansink E (2013) Hydro-economic modeling of water scarcity under global change: an application to the Gállego river basin (Spain). Reg Environ Chang 14:119-132. doi:10.1007/s10113-013-0472-0

Gómez-Gómez CM, Pérez-Blanco CD (2014) Simple myths and basic maths about greening irrigation. Water Resour Manag. doi:10.1007/s11269-014-0725-9

Gómez CM, Gutierrez C (2011) Enhancing irrigation efficiency but increasing water use: the Jevons' Paradox. EAAE 2011, Congress Change and Uncertainty Challenges for Agriculture, Food and Natural Resources. Zurich, Switzerland.

Gleick PH, Christian-Smith J, Cooley H (2011) Water-use efficiency and productivity: rethinking the basin approach. Water Int 36(7):784-798. doi:10.1080/02508060.2011.631873

Gutierrez-Martin C, Gomez Gomez CM (2011) Assessing irrigation efficiency improvements by using a preference revelation model. Span J Agric Res 9(4): 10091020. doi:10.5424/sjar/20110904-514-10

Heumesser C, Fuss S, Szolgayová J, Strauss F, Schmid E (2012) Investment in irrigation systems under precipitation uncertainty. Water Resour Manag 26(11): 3113-3137

Huffaker R (2008). Conservation potential of agricultural water conservation subsidies. Water Resour Res 44(7). doi:10.1029/2007WR006183

Jackson TM, Khan S, Hafeez M (2010) A comparative analysis of water application and energy consumption at the irrigated field level. Agricl Water Manag 97:1477-1485

Lecina S, Isidoro D, Playán E, Aragüés R (2010) Irrigation modernization and water conservation in Spain: the case of Riegos del Alto Aragón. Agric Water Manag 97:1663-1675

Lankford B (2006) Localising irrigation efficiency. Irrig Drain 55:345-362

López-Baldovín MJ, Gutiérrez C, Berbel J (2006) Multicriteria and multiperiod programming for scenario analysis in Guadalquivir River irrigated farming. J Oper Res Soc 57:499-509. doi:10.1057/palgrave.jors.2602029.

López-Gunn E, Mayor B, Dumont A (2012) Implications of the modernization of irrigation systems. In: De Stefano L, Llamas MR (eds.) Water, agriculture and the environment in Spain: can we square the circle? CRC Press, pp 241-256 
Martin DL, Watts DG, Gilley JR (1984) Model and production function for irrigation management. J Irrig Drain Eng 110:148-165

MAPA-Ministry of Food, Agriculture, and Fishery (2001). Plan Nacional de Regadíos. Horizonte 2008. Madrid, Spain (in Spanish)

Peterson JM and Ding Y (2005) Economic adjustments to groundwater depletion in the High Plains: do water-saving irrigation systems save water? Am J Agric Econ 87(1):147-159

Pfeiffer L and Lin C-YC (2014) Does efficient irrigation technology lead to reduced groundwater extraction?: Empirical evidence. J Environ Econ Manag 67:189-208 doi/10.1016/j.jeem.2013.12.002

Playán E, Mateos L (2006) Modernization and optimization of irrigation systems to increase water productivity. Agric Water Manag 80:100-105

Qureshi ME, Schwabe K, Connor J, Kirby M (2010) Environmental water incentive policy and return flows. Water Resour Res 46(4). doi:10.1029/2008WR007445

Rodríguez Díaz JA, Pérez Urrestarazu L, Camacho Poyato E, Montesinos P (2011). The paradox of irrigation scheme modernization: more efficient water use linked to higher energy demand. Span J Agric Res 9(4):1000-1008

Rodríguez Díaz JA, Pérez Urrestarazu L, Camacho Poyato E, and Montesinos P (2012) Modernizing water distribution networks - lessons from the Bembézar MD irrigation district, Spain. Outlook on Agric 41(4):229-236

Scheierling SM, Young RA, Cardon GE (2006) Public subsidies for water-conserving irrigation investments: Hydrologic, agronomic, and economic assessment. Water Resour Res 42(3). doi:10.1029/2004WR003809

Seckler D (1996) The new era of water resources management: from "dry" to "wet" water savings. IWMI Research Report 1, International Irrigation Management Institute, Colombo, Sri Lanka.

Soto-García M, Martínez-Álvarez V, García-Bastida PA, Alarcón F, Martin-Górriz B (2013) Effect of water scarcity and modernisation on the performance of irrigation districts in south-eastern Spain. Agric Water Manag 124:11-19

Spanish Government (2001) Real Decreto Legislativo 1/2001, de 20 de julio, por el que se aprueba el texto refundido de la Ley de Aguas (in Spanish) BOE-A-2001-14276. Available online: http://www.boe.es/buscar/doc.php?id=BOE-A-2001-14276 (accessed on 15 October 2013).

Törnqvist R, Jarsjö J (2012) Water savings through improved irrigation techniques: basinscale quantification in semi-arid environments. Water Resour Manag 26(4):949-962. doi:10.1007/s11269-011-9819-9

Ward FA, Pulido-Velazquez M (2008) Water conservation in agriculture can increase water use. Proc Natl Acad Sci 105(47):18215-18220. doi:10.1073/pnas.0805554105

Whittlesey N (2003) Improving irrigation efficiency through technology adoption: When will it conserve water? Dev Water Sci 50:53-62 